\title{
Attenuation of Oxidative Damage in Alloxan Induced Diabetic Rabbits Following Administration of the Extract of the Leaves of Vernonia amygdalina.
}

\author{
Owolabi, MA ${ }^{\mathrm{a}}$, Jaja, SI ${ }^{\mathrm{b}}$, Olatunji, $\mathrm{OJ}^{\mathrm{a}}$, Oyekanmi, $\mathrm{OO}^{\mathrm{a}}$, Adepoju, S \\ ${ }^{a}$ Natural Product Laboratory, Department of Pharmaceutical Chemistry, Faculty of Pharmacy, University of Lagos, \\ Lagos, Nigeria. ${ }^{b}$ Department of Physiology, College of Medicine, University of Lagos. P.M.B. 12003, Lagos, Nigeria.
}

\begin{abstract}
Introduction: Diabetes is a disease that constitutes multiple sources of free radicals, thus oxidative stress is expected to have a double impact. Since oxidative stress is mediated by hyperglycemia-induced generation of free radical, it is supposed that compounds with hypoglycemic and antioxidative properties would be useful antidiabetic agents. Our study investigated the use of $V$. amygdalina as a potential hypoglycemic and antioxidative agent by testing its effect on the antioxidant biomarkers and lipid peroxidation. Methods: Dried leaves of $V$. amgydalina were extracted for 48 hrs and freeze dried. Acute toxicity was investigated in 25 rats. Thirty six rabbits were divided into 6 groups: groups I - III were normal; diabetes was induced in groups (IV - VI). Groups I and IV were normal and diabetic controls respectively. The animals were treated with aqueous leaf extract of $V$. amygdalina. Blood samples were collected and used for the study. Results: The reduction in body weight in the diabetic groups was regained following administration of the extract of $V$. amgydalina. The extract is considered safe and had little or no effect on blood glucose, MDA and GSH levels of the normal rabbits. Extract significantly reduced glucose and MDA concentrations but increased GSH levels in the diabetic rabbits. Similarly, the extract had no effect on the activities of SOD, CAT and GPx in normal rabbits, however in diabetic rabbits, the enzymes activities increased dose-dependently. Conclusion: This finding provides basis for the use of $V$. amgydalina as potential antidiabetic antioxidant agent and may be useful for its hypoglycemic property.
\end{abstract}

Keywords: Diabetes mellitus, Free radical, lipid peroxidation, Oxidative stress, Vernonia amygdalina.

*Correspondence: mbangsandra@yahoo.com; Telephone: +234 8029438968

DOI: $10.5530 /$ ax.2011.3.13

\section{INTRODUCTION}

With oxidative stress linked to metabolic or vascular disorder, diabetes becomes the best disease for studying the consequences of oxidative stress and its treatment. ${ }^{[1]}$ Diabetes mellitus is a multifactorial disease characterized by hyperglycemia, ${ }^{[2,3]}$ lipoprotein abnormalities, ${ }^{[4]}$ raised basal metabolic rate, ${ }^{[5]}$ defect in reactive oxygen species scavenging enzymes ${ }^{[6]}$ and high oxidative stress induced by the generation of highly reactive free radicals which are also involved in pancreatic destruction. ${ }^{[2,7]}$ Insufficient removal of these free radicals can lead to oxidative damage to membranes; enhance susceptibility to lipid peroxidation, enzyme inactivation and nucleic acid damage. ${ }^{[8,6]}$

Since oxidative stress is mediated by hyperglycemiainduced generation of free radical, it became clear that lowering blood glucose as well as scavenging the free radicals may ameliorate the oxidative stress thus providing an effective strategy for reducing diabetic mellitus and its complications. ${ }^{[9]}$ Hence compounds with both hypoglycemic and antioxidative properties would be very useful antidiabetic agents. We therefore considered a known hypoglycemic plant, Vernonia amygdalina and its effect on some endogenous biomarkers of oxidative stress: superoxide dismutase (SOD), glutathione peroxidase (GPx) and catalase (CAT) and lipid peroxidation product, malonialdehyde (MDA) following the administration of the aqueous leaf extract of this plant to normal or alloxan-induced diabetic rabbits.

$V$. amygdalina Del. (compositeae) is of interest due to its biological activities, especially regarding its antioxidant, anticancer, antiviral, hypoglycemic and anti-inflammatory 
activities. $^{[10,11,12]}$ It has been reported that the beneficial effect of $V$. amygdalina may be attributed at least in part to its antioxidant action. ${ }^{[13]}$

\section{MATERIALS AND METHODS}

\section{Collection and preparation of the crude extract of $V$. amygdalina}

Fresh leaves of $V$. amygdalina were collected in December, 2006 in the early hours of the morning from Tanke district of Kwara State, Nigeria and identified by Mr. G. Ibhanesebhor of the Forestry Research Institute of Nigeria (FRIN) Ibadan, Nigeria. A voucher specimen has been deposited in the FRIN herbarium (no. - FHI 104046). The plant material dried at room temperature for 4 days was powdered and extracted into water $(\mathrm{pH}$ 5.63) using soxhlet extractor for 48 hours. The aqueous extract was freeze dried to obtain a yield of $68.74 \mathrm{~g}$ $(38.19 \%)$ from $180 \mathrm{~g}$ of the powdered plant material. The crude extract residue was stored in impervious amber bottle until used.

\section{Chemicals and Instrument}

All reagents were of analytical grade and purchased from sigma chemical company, unless otherwise stated. Glacial acetic acid, sodium chloride were from British Drug Houses (BDH), riboflavin was a donation from Chemiron International, Lagos Nigeria. Aluminum foil lined box fitted with $15 \mathrm{~W}$ fluorescent lamp was fabricated in our laboratory. The UV-Visible spectrophotometer was Agilent 8453 (Serial No. CN02500898; Product No. G1103A; Agilent technologies, Hewlett-Packard, Germany). The absorbences were recorded by Agilent ChemStation software (Agilent, Palo Alto, USA) running on a Compaq compatible personal computer (HewlettPackard, Obregon, Mexico) with an Intel Pentium processor operating at 2,799 $\mathrm{MHz}$ under the Microsoft (Redmond, WA) Windows operating environment. The ChemStation also consists of an interface bus for data acquisition and a pinwriter HP DeskJet 5652 printer.

\section{Animals}

Twenty five Sprague Dawley rats of either sex (180-250 g) were used for the acute toxicity study, thirty six adult rabbits of either sex weighing between 1.6 and $2.5 \mathrm{~kg}$ were used for the oxidative stress study. The animals were cared for and used in accordance with the Institute of Laboratory Animal Research (ILAR) guidelines for care and use of animals in experimental studies. ${ }^{[14]}$ They were housed in a well-ventilated Laboratory Animal Centre of the College of Medicine of the University of Lagos, Nigeria under standard laboratory condition (12:12 h dark/light cycle). The animals were allowed to acclimatize for 3 weeks during which they had free access to commercial pellet diet (Pfizer Feeds, Ibadan, Nigeria, Plc.) and water ad libitium.

\section{Acute toxicity}

The acute toxicity was studied according to the method of Organization for Economic Co-operation and Development (OECD) guidelines. ${ }^{[15]}$ The rats were randomly shared into one control and four test groups of 5 rats per group, and were fasted for 18 hours before experimentation. Four doses of the crude extract $(5,10$, 15 and $20 \mathrm{~g} / \mathrm{kg}$ body weight) were administered orally by gastric probe; the control group received distilled water. Mortality was determined 24 hours after administration and the $\mathrm{LD}_{50}$ calculated. The animals were further observed for 2 weeks for possible delayed toxicity.

\section{Induction of experimental diabetes}

After the acclimatization period, diabetes was induced by a single intravenous injection of freshly prepared alloxan (150 mg/kg body weight) in normal saline through the marginal ear vein. Control rabbits received a similar volume of normal saline. Diabetes was evident within 3 days after administration of alloxan. The rabbits with blood glucose level of above $250 \mathrm{mg} / \mathrm{dl}$ as well as polydipsia, polyuria, glycosuria (indicated by Benedict's test for urine) were considered diabetic and were included in the study.

\section{Extract administration and blood collection}

Fasted rabbits $(12 \mathrm{~h}, 18$ diabetic +18 normal) were divided equally into 6 groups. Treatment with the extract started on the $3^{\text {rd }}$ day of alloxan treatment and was continued daily to the $10^{\text {th }}$ day. The extract was given orally as a single dose in the morning. Group I (normal control) received distilled water, groups II and III were given 100 or $400 \mathrm{mg} / \mathrm{kg}$ body weight extract respectively. Group IV (diabetic control) received distilled water while groups V and VI (diabetic treated) received extract as in groups II and III respectively. Blood sample, $8 \mathrm{ml}$, was collected from the retro orbital plexus of each animal after extract treatment. Three millitres of the blood was put into potassium oxalate and sodium fluoride bottles 
for blood glucose estimation, the remaining $5 \mathrm{ml}$ was put into heparinized bottle, centrifuged at $3000 \mathrm{~g}$ for 10 min; plasma was carefully collected using Pasteur pipette and used for lipid peroxidation and protein estimation. The packed RBCs were washed 3 times with normal saline to remove the buffy coat. The washed erythrocyte was used for the antioxidant enzymes determination. The changes in body weight of the rabbits were observed throughout the treatment period.

\section{Estimation of blood glucose}

Blood glucose was estimated spectrophotometrically according to the method of ${ }^{[16]}$ In principle, O-toluidine reagent condenses with aldehyde group of glucose to form an equilibrium mixture of a glycosylamine and the corresponding schiff base producing a green chromogen mixture which absorbs at a wavelength of $630 \mathrm{~nm}$. In the assay, $4.5 \mathrm{ml}$ of $3 \% \mathrm{w} / \mathrm{v}$ trichloroacetic acid was added to each blood sample, $0.5 \mathrm{ml}$ and centrifuged at $3000 \mathrm{~g}$ for $15 \mathrm{~min}$. To $1 \mathrm{ml}$ of the plasma was added $7 \mathrm{ml}$ of $\mathrm{O}$-toluidine reagent, mixed and placed in water bath at $100{ }^{\circ} \mathrm{C}$ for $30 \mathrm{~min}$. The mixture was cooled and absorbance taken at $630 \mathrm{~nm}$ within $30 \mathrm{~min}$. The amount of glucose per dl of blood in each sample was calculated in reference to standard glucose.

\section{Determination of protein}

Protein concentration was determined by Biuret method. ${ }^{[17]}$ Seven milliliters of reaction mixture contained $0.1 \mathrm{ml}$ plasma sample, $2.9 \mathrm{ml}$ deionized water, and $4.0 \mathrm{ml}$ Biuret reagent. For control, deionized water replaced the plasma sample. The standard mixture contained $0.25 \mathrm{ml} 6 \%$ bovine serum albumin. The mixtures were left to stand at $25^{\circ} \mathrm{C}$ for $30 \mathrm{~min}$ and the absorbances were measured at $540 \mathrm{~nm}$. An increasing intensity of violet color was related to higher percentage of protein concentration present in the reaction, calculated as AT: 30/AS: $30 \times$ conc. of S. Where, AT: 30 is the absorbance of plasma sample, AS: 30 the absorbance of standard at 30 min reaction time, and $\mathrm{S}$ is the standard.

\section{Antioxidant parameters}

\section{Lipid peroxidation}

Lipid peroxidation was determined by the method of Satoh 1978. ${ }^{[18]}$ The assay principle is based on the fact that malondialdehyde (MDA), a secondary product of lipid peroxidation reacts with thiobarbituric acid (TBA) in acidic medium to give a pink chromogen which is measured spectrophotometrically. One milliliter plasma was precipitated with $2 \mathrm{ml}, 10 \%$ trichloroacetic acid and centrifuged at $3000 \mathrm{~g}$ for $15 \mathrm{~min}$ and supernatant separated. To the supernatant was added $0.5 \mathrm{ml}$ glacial acetic acid and $0.5 \mathrm{ml} 0.33 \%$ TBA and the mixture kept in a water bath at $97^{\circ} \mathrm{C}$ for $45 \mathrm{~min}$, at cooling, the pink chromogen was extracted with $2 \mathrm{ml}$ butanol. The absorbance of the organic layer was measured at $535 \mathrm{~nm}$ and the thiobarbituric acid reactive substances (TBARS) produced were estimated using MDA standard curve.

\section{Glutathione assay}

The level of glutathione was estimated according to the method of Tietze 1969. ${ }^{[19]}$ as reported by Rahman et al., 2007. ${ }^{[20]}$ The assay principle is based on the reaction of GSH with Ellman's reagent: 5, 5'-dithio-bis (2-nitrobenzoic acid), DTNB which produces a yellow derivative chromophore: 5'-thio-2-nitrobenzoic acid, (TNB) with a maximum absorbance at $412 \mathrm{~nm}$. In the procedure, $0.5 \mathrm{ml}, 0.6 \%$ sulphosalicylic acid was added to $1 \mathrm{ml}$ plasma and centrifuge at $8000 \mathrm{~g}$ for $10 \mathrm{~min}$. The supernatant was removed using Pasteur pipette and used for the determination of total GSH. Briefly, to $0.6 \mathrm{ml}$ potassium phosphate-EDTA buffer in a cuvette was added $0.1 \mathrm{ml}$ sample and $0.12 \mathrm{ml}$ mixture of DTNB/ GR. The cuvette and its content were allowed to stand for $30 \mathrm{sec}$ and $0.06 \mathrm{ml} \mathrm{NADPH}$ was there after added. The cuvette was inverted to mix the content and absorbance taken at $412 \mathrm{~nm}$ within $2 \mathrm{~min}$ against a sample blank. The rate of formation of TNB is proportional to the concentration of GSH in the sample. The amount of GSH in the sample was determined from a standard curve.

\section{Determination of superoxide dismutase activity}

The superoxide dismutase was estimated using the photo oxidation method of ${ }^{[21]}$ in erythrocyte lysate. Two millitres of the washed erythrocyte was lysed by the addition of an equal volume of ice-cold deionized water $\left(4{ }^{\circ} \mathrm{C}\right)$. Mixture of chloroform, $0.3 \mathrm{ml}$ and ethanol, $0.5 \mathrm{ml}$ was added to precipitate hemoglobin ${ }^{[2]}$ and was centrifuged at $10000 \mathrm{~g}$ for $25 \mathrm{~min}$ and the supernatant used for SOD estimation. In principle, illumination of a solution containing riboflavin and methionine under aerobic condition generates superoxide anion $\left(\mathrm{O}_{2}^{-}\right)$which reduces nitroblue tetrazolium (NBT) to a blue formazan. The SOD was quantified in terms of its ability to scavenge the $\mathrm{O}_{2}^{-}$thus inhibiting the reduction of NBT. In the method, the reaction mixture $(2.7 \mathrm{ml})$ containing 1.17 $\times 10^{-6} \mathrm{M}$ riboflavin, $1.0 \times 10^{-2} \mathrm{M}$ methionine, $1.67 \times$ $10^{-4} \mathrm{M}$ NBT and diluted erythrocyte lysate in phosphate 
buffer $\mathrm{pH} 7.8$ was illuminated in an aluminum foil lined box fitted with $15 \mathrm{~W}$ fluorescent lamp for $15 \mathrm{~min}$ and colour development was monitored at $560 \mathrm{~nm}$. The SOD was estimated from a standard curve of bovine SOD. Preparation without erythrocyte was used as the blank. One unit of SOD is defined as the amount of enzyme required to inhibit the rate of reduction of NBT by $50 \%$ under specified condition.

\section{Determination of glutathione peroxidase}

Glutathione peroxidase (GPx) was determined by the method of Paglia and Valentine 1967.[23] with slight modification. In this assay, GPx catalyzes the reduction of $\mathrm{H}_{2} \mathrm{O}_{2}$ to water thus oxidizing glutathione (GSH). The oxidized glutathione (GSSG) is then reduced by glutathione reductase to GSH and NADPH to NADP ${ }^{+}$. The rate of decreased in absorbance is directly proportional to GPx concentration and is measured at $340 \mathrm{~nm}$. In the procedure, washed erythrocyte was lysed with iced-cold deionized water $\left(4^{\circ} \mathrm{C}\right)$. To the lysate, $0.1 \mathrm{ml}$ was added $0.9 \mathrm{ml}$ of $0.05 \mathrm{M}$ phosphate buffer containing $0.005 \mathrm{M}$ of EDTA, $0.1 \mathrm{ml}$ of $0.0084 \mathrm{M}$ NADPH, $0.01 \mathrm{ml}$ of glutathione reductase and $0.1 \mathrm{ml}$ of $0.15 \mathrm{M} \mathrm{GSH}$. The mixture was placed in a cuvette and enzymatic reaction was initiated by addition of $0.1 \mathrm{ml}$ of $0.0022 \mathrm{M} \mathrm{H}_{2} \mathrm{O}_{2 ;}$ a change in absorbance was recorded at $340 \mathrm{~nm}$ for 4 min against a blank. The change in $\mathrm{A}_{340}$ due to NADPH oxidation was monitored and is indicative of GPx activity. Glutathione peroxidase activity was quantified using the relationship:

$$
\mathrm{U} / \mathrm{mg} \text { protein } / \min =\frac{\left(\frac{\Delta \mathrm{A}_{340}}{\min }\right)}{\frac{0.00622}{\mathrm{mg} \text { protein }}} \times \mathrm{d} \times \mathrm{TV} / \mathrm{SV} .
$$

In which $0.00622 \mu \mathrm{M}^{-1} \mathrm{~cm}^{-1}$ is the extinction coefficient for NADPH at $340 \mathrm{~nm}, \mathrm{~d}$ is the path length of the cuvette, TV is the total volume and SV is the sample volume.

\section{Determination of catalase activity}

The catalase activity was determined based on the disappearance of added hydrogen peroxide in the presence of enzyme source. The assay was performed based on the method of ${ }^{[24]}$ in erythrocyte lysate. An aliquot, $0.5 \mathrm{ml}$ of the lysate was placed in a tube containing $0.5 \mathrm{ml}$ of $1.5 \mathrm{mM} \mathrm{H}_{2} \mathrm{O}_{2}$ and $1 \mathrm{ml}$ of $0.01 \mathrm{M}$ phosphate buffer $\mathrm{pH}$ 7. The reaction was stopped at $25 \mathrm{~min}$ by the addition of $2 \mathrm{ml}$ of peroxidase reagent containing peroxidase and the chromogen (dimethoxybenzidine).
The absorbance of the colour formation due to the oxidation of the chromogen in the presence of the peroxidase was measured spectrophotometrically at 505 $\mathrm{nm}$ against a blank which contained no $\mathrm{H}_{2} \mathrm{O}_{2}$ and a control which contained $1 \mathrm{ml}$ of $1 \mathrm{mM}$ sodium azide, an inhibitor of catalase. The intensity of the colouration was linearly related to the $\mathrm{H}_{2} \mathrm{O}_{2}$ concentration. The catalase activity was calculated using the formula:

Unit catalase/mg protein.min

$$
=\left(\operatorname{In}\left\{\frac{A_{o}-A_{b l}}{A_{t}-A_{b l}}\right\}\right) \times \frac{1}{\text { mg protein }} \times \frac{1}{25 \text { min }}
$$

Where In is the natural $\log , A_{t}$ is the absorbance at 25 min, $A_{b l}$ is the absorbance of blank and $A_{o}$ is the absorbance in the presence of sodium azide.

\section{Data and statistical analysis}

Data are expressed as mean \pm SD (standard deviation). Statistical analyses were performed using SPSS version16 (SPSS Inc., 233 South Wacker Drive, Chicago, IL 606066412; Patent No. 7,023,453). Analyses of the data were performed using Student's $t$ test. Values were considered to differ significantly if the $\mathrm{P}$ value was less than 0.05 or 0.001 .

\section{RESULTS}

Normal control rabbits gained weight significantly throughout the study period. A significant decrease in body weight was observed in the diabetic control rabbit when compared to the normal rabbits $(\mathrm{p} \leq 0.001$, Figure 1). The alloxan mediated body weight reduction was significantly attenuated following treatment with aqueous leaf extract of $V$. amgydalina in a dose dependent manner (100 and $400 \mathrm{mg} / \mathrm{kg}$ b.wt). The administration of the extract (100 and $400 \mathrm{mg} / \mathrm{kg}$ b.wt) to the normal treated rabbits showed a steady increase in the body weight of the rabbits comparable to the normal control. The acute toxicity study of the extract of $V$. amygdalina on the rat model was considered safe and no mortality was recorded.

The levels of glucose and MDA were notably increased $(p \leq 0.001)$ in the alloxan diabetic control with a decrease in GSH compared to the normal control (Table 1). The extract of $V$. amgydalina when administered to the diabetic treated rabbits significantly ( $\mathrm{p} \leq 0.05)$ reduced the glucose and MDA levels but increased the level of GSH. The effect was more pronounced in the diabetic group that received $400 \mathrm{mg} / \mathrm{kg}$ b. wt. of the extract. The extract 
had little or no effect on the blood glucose, MDA and GSH levels of the normal treated group.

The activities of the enzymes, superoxide dismutase (SOD), glutathione peroxidase (GPx), and catalase (CAT) in the normal or diabetic rabbits are presented in Table 2. These enzymes showed significant $(p \leq 0.001)$ decrease in their mean activities in the alloxan-induced diabetic control as compared to the normal control. Treatment with the extract of $V$. amygdalina elevated the mean

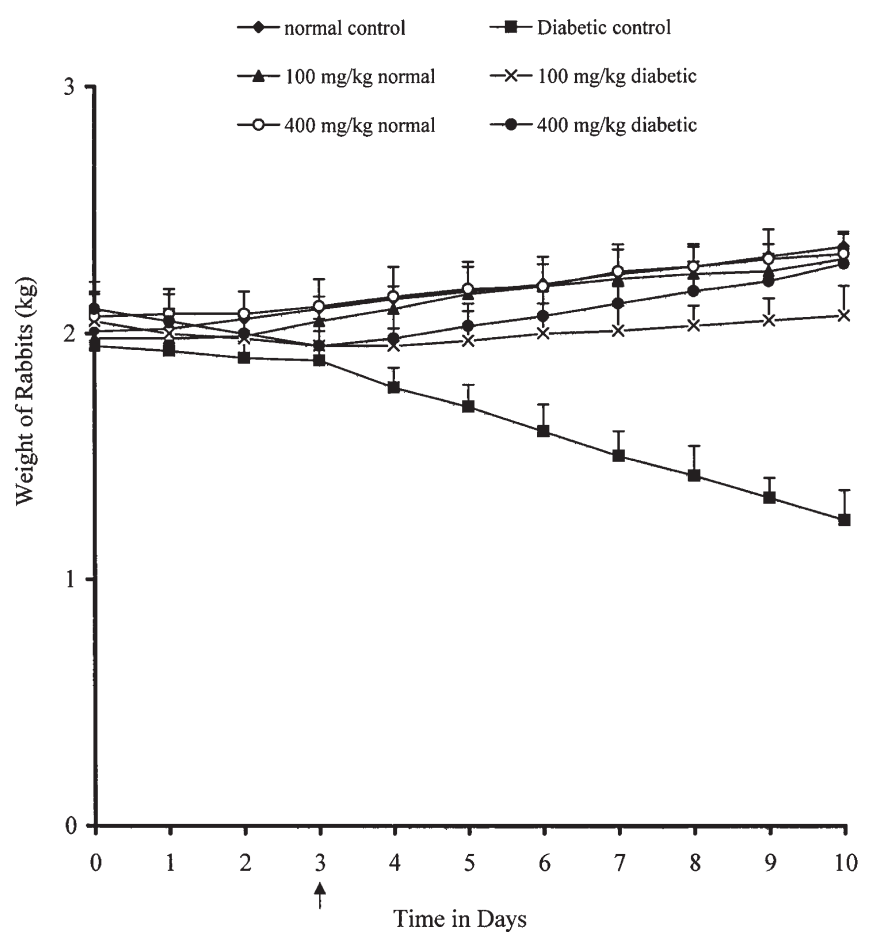

Figure 1. Weight of rabbits before and after $V$. amygdalina aqueous leaf extract administration. Values are expressed as mean $\pm S D, n=5$. Values were significant at $\mathrm{P} \leq 0.05$, indicates point of extract administration. activities of these enzymes in the diabetic control in a dose dependent fashion. There was no notable change in the activities of these enzymes in the normal group after treatment with the extract (100 and $400 \mathrm{mg} / \mathrm{kg}$ b.wt).

\section{DISCUSSION}

Hyperglycemia, the main symptom of diabetes increases the production of ROS and affects antioxidant reactions catalyzed by ROS scavenging enzymes. Alloxan-induced diabetic animals may exhibit most of the diabetic complications mediated through oxidative stress, hence valuable model for this study. Alloxan acts as a cytotoxin for $\beta$-cells of the islet of langerhans, causes diabetes by inducing cell necrosis. ${ }^{[25,26]}$ The ROS mediates the cytotoxic action leading to rapid $\beta$-cells destruction thus decreasing insulin secretion with ultimate rise in blood glucose..$^{[25,27]}$ The significant loss in body weight in the diabetic control could be due to accelerated muscle proteolysis, lipolysis and excessive fluid loss. ${ }^{[28]}$ The weight gain in the diabetic treated group indicates correction of body metabolism.

There is increasing evidence that oxidative stress caused by free radicals contributes to the development of diabetes mellitus. ${ }^{[29,30]}$ To elucidate the contribution of oxidative stress to the development of diabetes mellitus, we determined the effect of $V$. amygdalina on the level of lipid peroxidation product, malonialdehyde (MDA) which results from free radical damage to membrane components of the cells. ${ }^{[31]}$ The mean level of MDA increased significantly $(\mathrm{p} \leq 0.05)$ in the diabetic control compared to the normal group indicating increased oxidative stress in the diabetic rabbits. The significant

Table 1. The mean level of glucose, malondialdehyde (MDA) and glutathione (GSH) in normal or alloxan-induced diabetic rabbits after administration of the aqueous leaf extract of $V$. amgydalina.

\begin{tabular}{llll}
\hline \multicolumn{1}{c}{ Groups (Dose mg/kg) } & Glucose mg/dl & MDA nmol/mI & $\begin{array}{c}\text { GSH g/mg } \\
\text { protein }\end{array}$ \\
\hline Groups I & $109.6 \pm 1.17$ & $2.67 \pm 0.57$ & $3.46 \pm 0.33$ \\
Group II (100) & $110.2 \pm 1.31$ & $2.61 \pm 0.35$ & $3.48 \pm 0.11$ \\
Groups III (400) & $107.7 \pm 1.08^{\mathrm{c}}$ & $2.44 \pm 0.21^{\mathrm{c}}$ & $3.51 \pm 0.27^{\mathrm{c}}$ \\
Groups IV (diabetic) & $281.8 \pm 1.32^{\mathrm{a}, \mathrm{b}}$ & $5.81 \pm 0.29^{\mathrm{a}, \mathrm{b}}$ & $1.04 \pm 0.32^{\mathrm{a}, \mathrm{b}}$ \\
Groups IV (diabetic + 100) & $221.1 \pm 1.24$ & $4.93 \pm 0.11$ & $1.78 \pm 0.23$ \\
Groups IV (diabetic + 400) & $117.3 \pm 0.61^{\mathrm{d}}$ & $2.69 \pm 0.29^{\mathrm{d}}$ & $3.33 \pm 0.18^{\mathrm{d}}$ \\
\hline
\end{tabular}

Values are expressed as mean $\pm S D, n=5$. Parenthesis encloses doses. ${ }^{a}(\mathrm{P} \leq 0.001)$ when compared to normal control. ${ }^{\mathrm{b}}(\mathrm{P} \leq 0.001)$ when compared to diabetic treatment group. ${ }^{\mathrm{c}}(\mathrm{P} \geq 0.05)$ when compared to normal control. ${ }^{\mathrm{d}}(\mathrm{P} \geq 0.05)$ when compared to normal treatment group of comparable dose. (Glucose quantification: O-toluidine method). 
Table 2. The mean activities of superoxide dismutase, catalase and glutathione peroxidase in normal or alloxan-induced diabetic rabbits after administration of the aqueous leaf extract of $V$. amgydalina.

\begin{tabular}{|c|c|c|c|}
\hline Groups (Dose mg/kg) & $\begin{array}{l}\text { Superoxide } \\
\text { dismutase }^{1}\end{array}$ & Catalase $^{2}$ & $\begin{array}{l}\text { Glutathione } \\
\text { peroxidase }^{3}\end{array}$ \\
\hline Groups I & $5.31 \pm 0.82$ & $0.163 \pm 0.05$ & $8.86 \pm 8.83 \times 10^{-1}$ \\
\hline Groups II (100) & $5.87 \pm 1.22$ & $0.168 \pm 0.06$ & $8.93 \pm 5.34 \times 10^{-1}$ \\
\hline Groups III (400) & ${ }^{\circ} 6.34 \pm 0.91$ & ${ }^{\circ} 0.164 \pm 0.11$ & ${ }^{c} 9.27 \pm 8.41 \times 10^{-1}$ \\
\hline Groups IV (diabetic) & $\mathrm{a}, \mathrm{b} 2.92 \pm 1.13$ & ${ }^{a, b} 0.064 \pm 0.11$ & ${ }^{a, b} 4.12 \pm 6.45 \times 10^{-1}$ \\
\hline Groups IV (diabetic + 100) & $4.71 \pm 0.36$ & $0.124 \pm 0.08$ & $6.88 \pm 4.11 \times 10^{-1}$ \\
\hline Groups IV (diabetic + 400) & $\mathrm{d} 9.16 \pm 0.51$ & ${ }^{d} 0.169 \pm 0.04$ & ${ }^{\mathrm{d}} 8.98 \pm 4.06 \times 10^{-1}$ \\
\hline
\end{tabular}

Values are expressed as mean $\pm \mathrm{SD}, \mathrm{n}=5$. Parenthesis encloses doses. Enzyme activity measured in $50 \%$ inhibition of $\mathrm{NBT} / \mathrm{min}^{1}$; $\mathrm{U} / \mathrm{mg}$ protein $/ \mathrm{min}^{2,3}$. (Protein quantification: Biuret method). ${ }^{\mathrm{a}}(\mathrm{P} \leq 0.001)$ when compared to normal control. ${ }^{b}(\mathrm{P} \leq 0.001)$ when compared to diabetic treatment group. ${ }^{\mathrm{c}}(\mathrm{P} \geq 0.05)$ when compared to normal control. ${ }^{\mathrm{d}}(\mathrm{P} \geq 0.05)$ when compared to normal treatment group of comparable dose.

decreased in the level of MDA in normal range in a dose dependent manner after treatment with the extract of $V$. amygdalina suggests amelioration of the oxidative stress by the extract. This result coincides with the in-vitro study of ${ }^{[13]}$ who reported antiperoxidative effect of the water or ethanol extract of the leaves of $V$. amygdalina in the rat microsomal fraction

Glutathione $(\mathrm{GSH})$ is a non-enzymatic antioxidant present in millimolar concentrations in cells. ${ }^{[32,33]}$ It plays the role of an intracellular radical scavenger and as a co-substrate for peroxide detoxification by glutathione peroxidases. $^{[32,34,35]}$ Our study agreed with the reports of significant decreased in the plasma level of reduced glutathione in diabetes. ${ }^{[36,37,38]}$ In hyperglycemia, glucose is preferentially used in polyol pathway, ${ }^{[39]}$ consuming NADPH necessary for GSH regeneration by the GSH reductase thus resulting in GSH depletion and rendering the cell more susceptible to oxidative stress. From our study, hyperglycaemia in the alloxan induced-diabetic rabbits may have indirectly caused the depletion of GSH, however, administration of the aqueous extract of $V$. amygdalina to these groups increased the plasma level of GSH and significantly reduced blood glucose levels dose dependently. This finding indicates that polyol pathway may have been altered as a result of the decreased in the level of blood glucose thus increasing the biosynthesis of GSH. The fact that $V$. amygdalina reduced blood glucose level in diabetic rabbits had been previously reported. ${ }^{[10]}$

In diabetes, high level of glucose reaching the mitochondria leads to an overdrive of the electron transport chain resulting in overproduction of superoxide free radicals $\left(\mathrm{O}_{2}^{-}\right)$usually scavenged by superoxide dismutase (SOD), converting it to hydrogen peroxide and water. The failure of SOD to scavenge this $\mathrm{O}_{2}^{-}$results in oxidative stress. ${ }^{[1,40,41]}$ There are conflicting reports in the literature concerning the activities of the oxidative stress enzymes in diabetes mellitus. While some authors reported decrease in activities, ${ }^{[3,42,43]}$ others showed increase in activities of these enzymes. ${ }^{[44,45,46]}$ These discrepancies may be due to tissue specificity, technique used in assessing oxidative stress, duration or severity of the disease. In our study, SOD activity was significantly reduced in the diabetic control compared to the nondiabetic control and may be attributed to hyperglycemia inactivating the enzyme by glycation. ${ }^{[1,4]}$ The aqueous extract of $V$. amygdalina increased the activity of SOD dose dependently thus attenuating oxidative damage probably by preventing the potential glycation of the enzyme and an ultimate decrease in the enzyme activity.

Glutathione peroxidase is found in cytoplasmic and mitochondrial fractions of cells and plays a primary role in minimizing oxidative damage. It catalyzes the reduction of hydrogen peroxide and hydroperoxides formed from fatty acids to water thereby effectively removing toxic peroxides from living cells thus inhibiting the formation of free radicals. Oxidative damage to haemoglobin and cell membrane has been reported to reduce the activity of glutathione peroxidase. ${ }^{[48,49]}$ Similarly in our study, there was reduction in the activity of this enzyme. The significant reduction $(\mathrm{p} \leq 0.05)$ in the GPx activities in the diabetic control compared to either the normal control or diabetic treated may be due to glycation of the enzyme and inactivation of the enzymes by reactive oxygen specie, $\mathrm{H}_{2} \mathrm{O}_{2}$. Oxidation of glutathione by $\mathrm{H}_{2} \mathrm{O}_{2}$ and subsequent interaction of the active protein tyrosine phosphatase 
with oxidized glutathione formed mixed disulphide and resultant inactivation of the glutathione peroxidase.

Catalase is a hemeprotein found in nearly all organs of living organisms and catalyzes decomposition of $\mathrm{H}_{2} \mathrm{O}_{2}$, a powerful and potentially harmful oxidizing agent to water and oxygen. ${ }^{[50]}$ The significant reduction $(\mathrm{p} \leq$ 0.05) in CAT activities in the diabetic control compared to either the normal control or diabetic treated may be due to excessive generation of superoxide anion $\left(\mathrm{O}_{2}^{-}\right)$ in diabetic state leading to inactivation of this enzyme as $\mathrm{O}_{2}^{-}$has been shown to reduce catalase activity. ${ }^{[4,51]}$ Also increase in MDA may cause reduction in CAT activity as it can cross link with amino group of proteins to form intra and intermolecular cross-link thereby inactivating several membrane bound enzymes. ${ }^{[52]}$ With the administration of the extract of $V$. amygdalina, there was increase in CAT activity which was comparable to the normal treated rabbits. This finding may suggest that the extract reduced the potential glycation of enzymes or they may reduce reactive oxygen free radicals and improve the activities of antioxidant enzymes.

\section{CONCLUSION}

Conclusively, there is increase free radical generation in rabbits induced with diabetes mellitus thus impairing antioxidant defense enzyme system, SOD, GPx, and CAT and increase in lipid peroxidation product. The administration of the aqueous extract of $V$. amygdalina significantly attenuated the impairment of these enzymes as well as increase in the level of lipid peroxidation. This finding provides basis for the use of $V$. amgydalina as potential antidiabetic antioxidant agent and may be useful for its hypoglycemic property.

\section{ACKNOWLEDGEMENTS}

The authors are most grateful to Messers Duncan and Micah for caring for the animals and the College of Medicine, University of Lagos, Nigeria for allowing the use of the Central Research Laboratory.

\section{REFERENCES}

1. Wiernsperger NF. Oxidative stress as a therapeutic target in diabetes: revisiting the controversy. Diabetes Metab. 2003; 29:576-85.

2. Sharma VK, Kumar S, Patel HJ, Hugar S. Hypoglycemic activity of Ficus glomerata in alloxan induced diabetic rats. International Journal of Pharmaceutical Sciences Review and Research 2010; 1(2):18-22.
3. Ugochukwu NH, Babady NE, Cobourne M, Gasset SR. The effect of Gangronema latifolium extracts on serum lipid profile and oxidative stress in hepatocytes of diabetic rats. Journal of Biosciences 2003; 28(1):1-5.

4. Scoppola A, Montecchi FR, Mezinger G, Lala A. Urinary mevalonate excretion rate in type 2 diabetes: role of metabolic control. Atherosclerosis 2001; 156:357-61.

5. Owu DU, Antai AB, Udofia KH, Obembe AO, Obasi KO, Eteng MU. Vitamin $C$ improves basal metabolic rate and lipid profile in alloxan-induced diabetes mellitus in rats. Journal of Biosciences 2006; 31(5):575-9.

6. Kesavulu MM, Giri R, Kameswara RB, Apparao C. Lipid peroxidation and antioxidant enzyme levels in type 2 diabetic with microvascular complications. Diabetic Metabol., 2000; 26:387-92.

7. Nayeemunnisa A. Alloxan diabetes-induced oxidative stress and impairment of oxidative defense system in rat brain: neuroprotective effects of cichorium intybus. Int. J. Diabetes \& Metabolism, 2009; 17:105-9.

8. Farombi EO, Fakoya A. Free radical scavenging and antigenotoxic activities of natural phenolic compounds in dried flowers of Hibiscus sabdariffa L. Molecular Nutrition and Food Research 2005; 49:1120 8. doi:10.1002/mnfr.200500084.

9. Johansen JS, Harris AK, Rychly DJ, Ergul A. Oxidative stress and the use of antioxidants in diabetes: linking basic science to clinical practice. Cardiovasc Diabetol. 2005; 29(4)1:5.

10. Ekpenyong ME, Ukpo GE, Odukoya A, Coker HAB. Antihyperglycemic effect of the leaves of Vernonia amgydalina del. on blood glucose level of normal and diabetic rabbits. J. Pharmacy and Pharmaceutical Science, 1999; 5(2):51-4.

11. Izevbigie EB, Bryant JL, Walker A. Edible Vernonia amygdalina leaf extract inhibits extracellular signal-regulated kinases and human breast cancer cell growth.J.Nutr.2003;133:3851S-3868S.

12. Ojiako OA, Nwanjo HU. Is Vernonia amygdalina hepatotoxic or hepatoprotective? Response from biochemical and toxicity studies in rats. African Journal of Biotechnology 2006; 5(18):1648-51.

13. Owolabi MA, Jaja SI, Olatunji, OO, Olatunji OJ. Evaluation of the antioxidant activity and lipid peroxidation of the leaves of Vernonia amygdalina. Journal of Complementary and Integrative Medicine 2008; 5(1), article 21. doi: 10.2202/1553-3840.1152

14. Guide for the Care and Use of Laboratory Animals 1996. Institute of Laboratory Animal Research (ILAR) Commission on life Science, National Research Council. Available from: http:// www.nap.edu/openbook.php?record_id $=5140$ \&page $=21$

15. "Guidance document on acute oral toxicity testing" Series on testing and assessment No. 24, 2001 Organization for economic cooperation and development OECD environment, health and safety publications, Paris. Available from: www.oecd.org/ehs.

16. Dubowski, KM. Carbohydrates: In the Fundamentals of Clinical Chemistry $2^{\text {nd }}$ Edition Saunder Press, Philadelphia. 1962; 161-5.

17. Kingsley GR. The direct Biuret method for the determination of serum protein is as applied to photoelectric and visual colorimetry. J Lab Clin Med. 1942; 27:840-5.

18. Satoh K. Serum lipid peroxides in cerebrovascular disorders determined by new colorimetric method. Clin. Chem. Acta 1978; 90:37-43.

19. Tietze F. Enzymic method for quantitative determination of nanogram amounts of total and oxidized glutathione:applications to mammalian blood and other tissues. Anal. Biochem 1969; 27:502-22.

20. Rahman I, Kode, Biswas SK. Assay for quantitative determination of glutathione and glutathione disulfide levels using enzymatic recycling method. Nature protocols 2006; 1(6):3159-65. 
21. Beauchamp C, Fridovich I. Superoxide dismutase: Improved Assays and an Assays Applicable to Acrylamide Gels. Analytical Biochemistry 1971; 44:276-87.

22. Sun Y, Oberley LW, Li Y. A simple method for clinical assay of superoxide dismutase. Clin. Chem 1988; 34(3):497-500.

23. Paglia DE, Valentine WN. Studies on the quantitative and qualitative characterization of erythrocyte glutathione peroxidase. J. Lab. \& Clin. Med. 1967; 70(1):158-69.

24. Brannan TS, Maker HS, Raes IP. Regional distribution of catalase in the adult rat brain. Journal of Neurochemistry 1981;39(1):307-9.

25. Khushk I, Dahot MU, Baloach SA, Bhutto MA. The evaluation of soybean extracts in alloxan-induced diabetic rabbits. World Applied Sciences Journal 8 (Special Issue of Biotechnology \& Genetic Engineering); 2010:22-5.

26. Jorns A, Munday R, Tiedge M, Lenzen S. Comparative toxicity of alloxan, $\mathrm{N}$-alkyl-alloxans and ninhydrin to isolated pancreatic islets in vitro. J. Endocrinol. 1997; 155:283-93.

27. Deewanjee S, Bose SK, Sahu R, Mandal SC. Antidiabetic effect of matured fruits of Diospyros peregrine in alloxan-induced diabetic rats. International J. Green Pharmacy 2008; 2(2):95-9.

28. Alberti KGMM,Zimmet PZ. Definition, diagnosis and classification of diabetes mellitus and its complications. Part 1: Disguises and classification of diabetes mellitus. Provisional Report of WHO consultations. Diabet. Med. 1998; 15:539-53.

29. Mahdi AA, Chandra A, Singh RK, Shukla S, Mishra LC, Ahmad S. Effect of herbal hypoglycemic agents on oxidative stress and antioxidant status in diabetic rats. Indian Journal of Clinical Biochemistry 2003; 18(2):8-15.

30. Bambolkar S, Sainani GS. Evaluation of oxidative stress in diabetics with or without vascular complications. J. Asso. Phys. India 1995; 43:10-2.

31. Plaa GL, Witschi, H. Chemical, drugs and lipid peroxidation. Ann. Rev. Pharmacol. Toxicol. 1976; 16:125-41

32. Moussa SA. Oxidative stress in diabetes mellitus. Romanian J. Biophys. 2008; 18(3):225-36.

33. LU SC. Regulation of hepatic glutathione synthesis: current concepts and controversies, FASEB J., 1999; 13:1169-83.

34. Gregus Z, Fekete T, Halaszi E, Klaassen CD. Lipoic acid impairs glycine conjugation of benzoic acid and renal excretion of benzoylglycine. Drug Metab. Dispos. 1996; 24:682-688.

35. Winterbourn CC. Concerted antioxidant activity of glutathione and superoxide dismutase. In: Packer L, Fuchs J, eds. Biothiols in health and disease, New York: Marcel Dekker Inc, 1995; 117-34.

36. Ceriello A. Oxidative stress and glycemic regulation. Metabolism 2000; 49:27-29.

37. Giugliano D, Ceriello A, Paolisso G. Oxidative stress and diabetic vascular complications. Diabetes Care 1996; 19:257-67.

38. Seghrouchni I, Drai J, Bannier E, Rivière J, Calmard P, Garcia I, Orgiazzi J, Revol A, Oxidative stress parameters in type I, type II and insulin-treated type 2 diabetes mellitus; insulin treatment efficiency, Clinica Chimica Acta 2002; 321:89-96.

39. Lee AY, Chung SS. Contributions of polyol pathway to oxidative stress in diabetic cataract, FASEB J. 1999; 13:23-30.

40. Firdaus M, Astawan M, Muchtadi D, Wresdiyati T, Waspadji S, Karyono SS. Prevention of endothelial dysfunction in streptozotocin-induced diabetic rats by Sargassum echinocarpum extract. Med. J. Indones 2010; 19:32-35.

41. Dandu AM, Inamda NM. Protective effects of Andrographis paniculata against endothelial dysunction in diabetic wistar rats. Journal of Pharmacology and Toxicology 2008; 3(4):311-17.

42. Coskum O, Kanter M, Korkmaz A, Oter S. Quercetin, a flavonoid antioxidant, prevents and protects streptozotocin-induced oxidative stress and $\beta$-cell damage in rat pancreas. Pharmacol Res. 2005; 51:117-23.

43. Sekeroglu MR, Sahin H, Dulger H, Algun E. The effect of dietary treatment on erythrocyte lipid peroxidation, superoxide dismutase and glutathione peroxidase, and serum lipid peroxidation in patients with type 2 diabetes mellitus. Clin. Biochem. 2000; 33:669-74.

44. Dias AS, Porawski M, Alonso M, Marroni N, Collado PS, González-Gallego J. Quercetin decreases oxidative stress, NF-kB activation, and iNOS overexpression in liver of streptozotocin-induced diabetic rats. J. Nutr. 2005; 135:22992304.

45. Aliciguzel Y, Ozen I, Aslan M, Karayalcin U. Activities of xanthine oxidoreductase and antioxidant enzymes in different tissues of diabetic rats. J Lab Clin Med. 2003; 142:172-7.

46. Sanders RA, Rauscher FM, Watkins JB. Effects of quercetin on antioxidant defense in streptozotocin-induced diabetic rats. $J$ Biochem Mol Toxicol. 2001; 15:143-9.

47. Sozmen EY, Sozmen B, Delen Y, Onat T. Catalase/superoxide dismutase (SOD) and catalase/paraoxonase (PON) ratios may implicate poor glycemic control. Arch. Med. Res. 2001; 32:283-7.

48. Das KS, Vasudevan DM. Monitoring oxidative stress in patients with non-alcoholic and alcoholic liver diseases. Indian Journal of Clinical Biochemistry 2005; 20(2):24-8.

49. Zima T, Fialova L, Mestek O, Janebova M, Crkovska J, Malbehan I, Stipek S, Mikulikova L, Popov P. Oxidative stress, metabolism of ethanol and alcohol related diseases. J. Biomed. Sci. 2001; 8(1):59-70.

50. Chelikani P, Fita I, Loewen PC. Diversity of structures and properties among catalase. Cell Mol. Life Sci. 2004; 61(2):192208. doi:101007/s00018-003-3206-5.

51. Kono Y, Fridovich I. Superoxide radical inhibits catalase. J. Biol. Chem. 1982; 257:5751-54.

52. Kiklugawa K, Koraugi $\mathrm{H}$, Asakura T. Effect of MDA, a product of lipid peroxidation on the function and stability of haemoglobin. Arch. Biochem. Biophys. 1984; 229-7. 